\title{
The honey of Plebeia molesta and other melliferous insects in the peasant culture of the Northwest of Córdoba, Argentina
}

\author{
Melisa Gabriela Geisa ${ }^{1 *}$ tand Norma Inés Hilgert ${ }^{2 t}$
}

\begin{abstract}
Bees called meliponas (family Apidae, tribe Meliponini) are native stingless bees (ANSA) whose products (honey and other elements from the hive) have been employed by various indigenous and peasant cultures since ancient times. This study lists the native honeybee species known to criollos from northwest Córdoba. It also analyzes in particular the relationship between peasants living in three different environments in the region and the uses they assign to Plebeia molesta honey. Semi-structured interviews were conducted with 42 key interlocutors. To analyze the obtained information qualitative and quantitative methods were used. Local people recognize 4 native melliferous insects, being the one called "quella" the most important. Its honey is used mainly for medicinal purposes and as food. The predominant use as medicine is ingestion in pure form (45\%) and the most frequently treated conditions are those related to the respiratory system $(88.53 \%)$. In relation to the changes perceived in the availability of this resource, $75 \%$ of the interlocutors considered that the frequency of nest encounters has decreased in the last decades. The assigned uses of honey show a high variability in relation to the socio-cultural and occupational characteristics of the inhabitants. It is concluded that this honey is a valuable resource for farmers in the region. Given the perceived decrease of these populations, management and conservation strategies should be implemented that, incorporating the peasant point of view, guarantee their accessibility and perpetuity.
\end{abstract}

Keywords: Native Stingless Bee; Dry Chaco; Ethnobiology; Criollos; Meliponas.

1 Instituto de Antropología de Córdoba (IDACOR), Universidad Nacional de Córdoba - CONICET. Hipólito Irigoyen 174 Córdoba, Argentina. CP 5000.

2 Instituto de Biología Subtropical, Universidad Nacional de Misiones - CONICET. Facultad de Ciencias Forestales, UNaM. Asoc. Civil CelBA. Bertoni 85, Puerto Iguazú, Misiones, Argentina. CP 3370.

*Corresponding author. $\mathrm{E}$ E-mail address: MGG (meligeisa@gmail.com), NIH (normahilgert@yahoo.com.ar)

\section{INTRODUCTION}

The origin of hymenoptera in the Neotropics dates back 220 to 300 million years resulting in a group of insects adapted to different environments. Their capacities have been associated with complex behaviors, and eusocial behavior has been observed in some taxa (Nieves-Aldrey et al. 2006). Meliponas or meliponid bees, highly social stingless bees belonging to the Apidae Family are comprise in this group (Michener 2007). According to their location and morphology, these bees form permanent 
colonies and build diverse types of nests, which can be found in tree holes, in the ground, hanging, in living trunks, in building constructions-like the interstices of hollow bricks or between the stones of pircas-or walls- (Álvarez et al. 2016; Arenas 2003).

Taking into account recent descriptions (Álvarez et al. 2016), in Argentina there are 34 species of native stingless bees (ANSA) grouped into 18 genera. Plebeia is one of the most diverse genera, currently represented in the country by six species, two of which reach the southernmost distribution of the tribe in the Neotropics (Roig Alsina et al. 2013). In particular, Plebeia catamarcensis (Holmberg 1903) and P. molesta (Puls 1868) are cited for the province of Córdoba (Argentina), although it is possible that at least one other species inhabits the region.

Bees are recognized worldwide for their pollination services linked to the production of food on a global scale. In some countries they have been declared the most important living species on the planet due to its direct contribution to the maintenance and perpetuity of biodiversity (ICl Forestal 2018). About $80 \%$ of the species of flowering plants depend on zoo-pollination and at least 35\% of the world agricultural production is pollinated by bees, birds and bats, increasing the yield of 87 of the world main crops according to FAO (2018). In contrast, in recent years there has been concern about the decrease in populations of honey bees as well as those of other wild pollinators associated with changes in land use and the incorporation of agrochemicals (EFE 2016; IPBES 2016; UICN 2016; Lázaro and Tur 2018).

The Gran Chaco constitutes a phytogeographic unit located on a wide sedimentary plain of approximately 1,066,000 km2, distributed between Bolivia (with 11.6\%), Paraguay (25.4\%), Brazil $(0.8 \%)$ and Argentina (62.2\%) (The Nature Conservancy et al. 2005). It houses about 20 species of honeybee hymenoptera, including bees with and without stings and wasps (Kamienkowski and Arenas 2012). The state of conservation of this biome in the Province of Córdoba (Argentina) shows a wide gradient which ranges from areas of wellpreserved natural vegetation, plots of intermediate use for livestock and areas of intensive agricultural use with marked alteration of vegetation and soil (Tapella 2012). In recent years, the process of agriculturization has been increasing to the detriment of livestock production, mainly for the cultivation of soybean (Silvetti 2010). The advance of the agricultural frontier affected the surface of native forests, being the vegetation of the Chaco forest the most disturbed. This process of degradation of native forests is accompanied by a drastic reduction of local biodiversity as well as of the benefits these ecosystems provide. At the same time it has influenced the perception, valuation and preservation of environmental and socio-cultural services by the different actors in the region (Tapella 2012) resulting in changes in the ways of life of the peoples who have inhabited the place since ancient times (Bertonatti 2017).

According to Soldati (2015) the transmission of knowledge is one of the elementary processes in cultural evolution and in the relationship between people and their understanding of nature. Pursuant to this concept, in each innovation event, new information would be selected, creating adapted knowledge and enabling an effective process from an evolutionary point of view. In studies carried out in neighboring regions, different factors were identified as modelling the response of the population to environmental changes. Age, sex, economic 
activity and education appear as important; as well as idiosyncratic characteristics, family traditions, access to health services and changes in lifestyle (Arias Toledo 2009; Arias Toledo et al. 2010; Furlan et al. 2011; Martínez and Luján 2011; Trillo et al. 2007). In the study of some resources in particular, geographic isolation was also reported as one of the contributing factors to the conservation of practices and uses (Hilgert and Gil 2006).

In this dynamic context, ethnobiology as a branch of science that analyzes how human beings interact with the environment (Posey 1987a, b; Toledo et al. 1995) is a very useful tool. From a socio-ecological approach, ethnobiological studies can establish the basis for a rational management of biological resources and the design of local development strategies that contribute to the conservation of regional biodiversity (De Albuquerque 1999). Studying the perceptions, valuations and knowledge of the populations on their surroundings and the resources available, ethnobiology allows to put in dialogue different epistemologies to search together solutions to current problems that threaten the integrity of ecosystems and cultures (Argueta Villamar et al. 2018; Avendaño 2010; Gudynas 2011). As part of the corpus, different species are categorized and named according to perception, relationship and meaning in the local community (Hilgert 2007). Thus, the registration of local nomenclature provides valuable information for studies that, based on the analysis of folk systematics (also called ethnotaxonomy), elucidate the cultural significance of the different biological groups, taking into account the descriptive or explanatory power of given names (Berlin 1992; Cotton 1996).

In our country, the use of ANSA honeys different social groups (indigenous peoples, criollos and colonists) has been cited in works analyzing the material and symbolic importance of these insects and their products in the medicine and nutrition of different populations at present and in past times (Arenas 2003; Baquero and Stamatti 2007; Flores et al. 2018; INTA 2014; Kamienkowski and Arenas 2012; Kujawska et al. 2012; Loiácono et al. 2016; Martínez 2010; Medrano and Rosso 2010; Puigrós 2006; Suriano and Lobato 2013; Torres et al.1998; Vitar 2000; Zamudio et al. 2010; Zamudio 2011; Zamudio and Hilgert 2011, 2012, 2017). However, data on the uses assigned to Plebeia genus is scarce. For Córdoba, the available information comes only from historical and literary sources. Records of native honey bee uses appear in documents that show the importance of this resource in terms of exchange and its use in the culture of native peoples (Serrano 1945; Stagnaro 2016). Besides, testimonies documenting the oral tradition of the peoples in the north of the province have recorded the use of "stick honey" made by meliponas for medicinal and nutritional purposes (Colectivo Relatos del Viento 2010; Rionda Cortina and Rosalia 2015).

In the present work, we analize stingless bees and other melliferous insects recognized by local inhabitants and registered the names assigned to them. In a second stage, different aspects are analyzed in depth in relation to the species most frequently cited, Plebeia molesta. The objectives of this study were: 1 ) to recognize the proportion of young adults and older adults identified as key interlocutors, 2) to identify the list of known native melliferous insects and the names assigned to the among residents of three different environments in northwest Córdoba. In relation to Plebeia molesta: 3) to survey and compare the local uses of honey and 4) to 
inquire about the perception of changes in abundance over time. Currently, the scientific paradigm of broad perspective on the contribution nature makes to people's quality of life is increasingly accepted (Díaz et al. 2018). From this perspective, the question guiding the analysis of Plebeia molesta considers the relationship between the uses assigned to its honeys and its consumers, among which different sociocultural characteristics ${ }^{1}$ can be observed. We expect to find similar uses among people who: a) live in the same environment, b: are more related to each other (defined as labour or family associations) and c: whose main productive activities encourage a similar link with the natural environments where they live.

\section{MATERIAL AND METHODS}

The Northwest region of the Province of Córdoba is included in the natural region of the Dry Chaco of Argentina (Morello et al. 2012), characterized by having large seasonal and daily thermal amplitudes, with an average of $26^{\circ} \mathrm{C}$ in summer and $16^{\circ} \mathrm{C}$ in winter. According to Tálamo (2006), it is in this environment where the highest absolute temperatures of South America are recorded, with very hot summers but with frequent frosts during the winter months (up to 10 per winter). The annual average of precipitations is $300 \mathrm{~mm}$, distributed in two seasons, a dry one from April to September and a humid one-which concentrates $80 \%$ of rains- from October to March (Morello et al. 2012). A decade ago, the original forest remnant was estimated at around $5 \%$ (Barchuk et al. 2009); given the continuous process of clearance, it is likely that these values overestimate the current situation. Between 2000 and 2015, 80\% (more than 130 thousand hectares) of the tree cover loss in the province was concentrated in the north-northwest arch (Agost 2017).

In the work area there are three natural environments, with different present vegetation, climate, soils and relief: Serrano Forest, Western or Plain Chaco Forest and the Salinas Coast. Between 500 and 1,300 m.s.n.m. the Serrano Forest is established with the presence of "molle" (Lithraea molleoides (Vell.) Engl., Anacardiaceae), "horco quebracho" (Schinopsis lorentzii (Griseb.) Engl., Anacardiaceae), "apple tree of the field" (Ruprechtia apetala Wedd., Polygonaceae) and "piquillin" (Condalia spp., Rhamnaceae) as characteristic species. In a decreasing altitudinal gradient, the Western or Plain Chaco Forest shows plants adapted to xerophytic environments, such as "white quebracho" (Aspidosperma quebracho-blanco Schltdl., Apocynaceae) -arboreal dominant species -, "algarrobo" (Prosopis spp., Fabaceae), "mistol" (Sarcomphalus mistol (Griseb.) Hauenschild., Rhamnaceae) and shrubs such as "jarilla" (Larrea divaricata Cav., Zygophyllaceae) and "garabatos" (Vachellia spp., Fabaceae). The terrain then turns in to the Salinas Coast, a plain forest in transition with halophytic plants, which, as they approach the salt itself form a scrub or perisaline shrub with species capable of resisting, tolerating or regulating the excess of salt, commonly succulent, with small leaves, or without them and of marked xerophytic aspect (Cosa and Dottori 2010) like "palta" (Maytenus vitis-idaea Griseb., Celastraceae), "rodajillo" (Plectrocarpa tetracantha Gillies ex Hook. \& Arn., Zygophyllaceae), among others, "deer grass" (Lippia salsa Griseb., Verbenaceae), species of Lycium spp. (Solanaceae), "palo azul" (Cyclolepis genistoides Gillies ex D. Don, Asteraceae), "vinagrillo" (Grahamia bracteata Hook. \& Arn., 
Anacampserotaceae), different species of the family Cactaceae as "cardón" (Stetsonia coryne (Salm-Dyck) Britton \& Rose), and various Quenopodiaceae ("jumes" and "cachiyuyos") such as Allenrolfea patagonica (Moq.) Kuntze, Suaeda divaricada Moq., Heterostachys ritteriana (Moq.) Ung.Sternb., and Atriplex argentina Speg., among others. For the nomenclature of the vegetation characteristic of each environment, we used the catalog of vascular plants of the Instituto de Botánica Darwinion (2018).

The work area is inhabited by peasant communities that maintain a diversified use of the native forest with management practices and production of old local trajectory; they generally own the land and are small or medium-sized livestock producers dedicated to raising goats, cows, horses, pigs and sheep (in that order of prevalence) (Sánchez 2013). They have been characterized as "criollos": people of Spanish-aboriginal mestizo roots who are descendants from native people, Comechingones and Sanavirones, and from immigrants who arrived to the region after the Spanish conquest (Grimaldi and Trillo 2018; Trillo et al. 2014, 2016; Trillo 2016; Trillo and Audisio 2018). Part of the local inhabitants involved in this study gather in native communities registered in the Instituto Nacional de Asuntos Indígenas (Res. $\mathrm{N}^{\circ}$ 115/2012 - Ministerio de Desarrollo Social de la Nación Argentina, access 05/2018). Likewise, another part of the population is part of the Movimiento Campesino de Córdoba; a group of 600 families of rural producers whose mission is to claim rural production and peasant life, guarantee access to resources, health, education and the right to land (Movimiento Nacional Campesino Indígena 2010). For the purposes of this study, will be referred to as "criollos" or "peasants" given that they are the names most commonly used by them and include the inhabitants of all the mentioned conditions.

Within the three environments described above, rural locations in sites with native forest in a good state of conservation were selected, within or close to provincial protected natural areas, within the Departments Cruz del Eje, Minas, Pocho, San Javier and Ischilín (Figure 1).

Rural domestic units were selected in the three environments in sectors in a good state of conservation (in relation to the regional landscape matrix). To define a domestic unit (sampling unit in this study) we followed Harris (1986), who considers it as an institution formed by a group of people who co-reside in the same dwelling, which do not necessarily have genealogical kinship, but make up the economic, residence and / or reproductive unit. Within each domestic unit, we worked with interlocutors identified as responsible for the administration of honey - or who maintain a greater contact and interest in this resource who were born in the place or have lived in the area 20 or more years. The visits were made between 2015 and 2017. For the identification of new domestic units we used the snowball technique (Bernard 2000). At the beginning of the activities, written informed consent was obtained from all those involved in the consultations and visits according to the established norms (Cano Contreras et al. 2015; ISE 2006). We interviewed 42 people of both sexes aged 19 to 80 living in the three types of environments (15 in the Serrano Forest, 11 in Salinas Coast and 16 in the Plain Forest), $14 \%$ of the interviewees were young adults under 35 years of age.

Semi-structured interviews on topics related to known native melliferous insects 


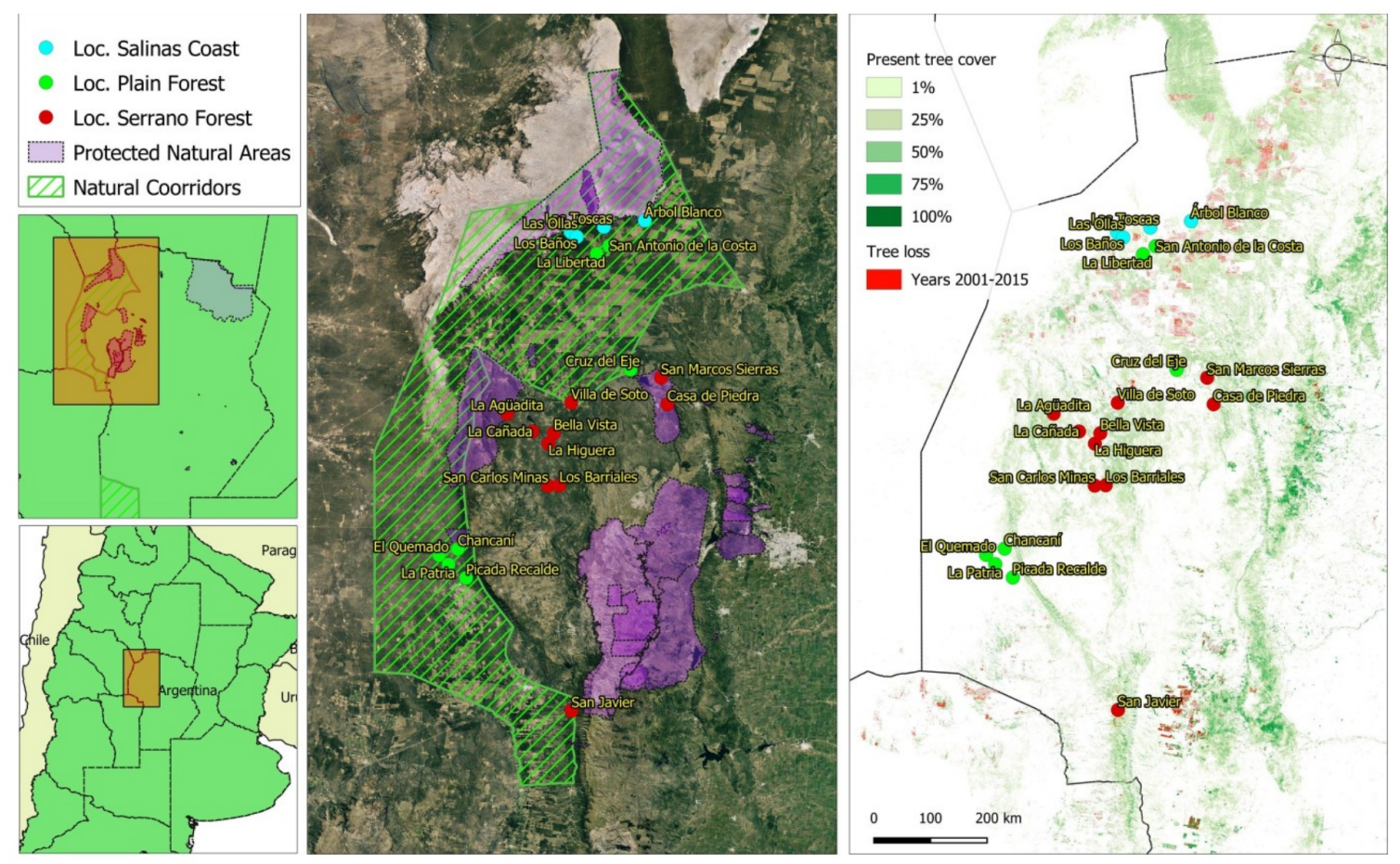

Figure 1. Study area. Locations visited in each environmental zone according to the Áreas Naturales Protegidas de la Provincia de Córdoba (Protected Natural Areas). The present tree cover (green) and its loss between 2001-2015 (red).

and their assigned names were carried out. The talk was deepened in the case of the species with the greatest number of reports to find out the local uses of honey and different ways of preparation and administration. Likewise, questions were included on the perception of changes in the distribution and abundance of nests over time as well as factors associated with these changes. To compare the local uses of honey and the sociocultural and occupational characteristics, the following variables were considered:

- Degree of isolation: distance to urban centers, roads condition throughout the year, means of mobility of the inhabitants (automobile, motorcycle, animal or pedestrian), presence of public transport

- Age of the interlocutors

- Link with the resource: the way of obtaining it, the assigned use and the way of preparation and application. labour)

- Link between residents (family or

- Main productive activities

- Environment where the domestic unit is located.

In the company of the peasants, we searched for natural nests of native stingless bees and took samples of their honeys and insects (the latter were kept in alcohol and identified by Dr. L. Álvarez in División de Entomología, Facultad de Ciencias Naturales y Museo, UNLP (Buenos Aires, Argentina). The other melliferous insects mentioned by the inhabitants were observed in the field and determined at species level by means of the Moure's Bee Catalogue (2018) and the Systematic List of Insects of Argentina from EcoRegistros (2018). We took samples of bees and honey from 54 wild nests. For the purposes of this study, we considered "wild honeys" those produced by 
native insects, including different types of hymenoptera (wasps, bumblebees, and stingless bees).

Of the aforementioned variables, we evaluated the relationship between the degree of isolation, link with the resource, main productive activity and environment. A Multiple Correspondence Analysis (MCA) was carried out in the $\mathrm{R}$ software with the FactoMineR package. The MCA analysis is useful to describe the factors that contribute most to explaining the total variability. The technique objective is to summarize a large amount of data in a reduced number of dimensions, with the least possible loss of information applied to categorical or ordinal variables (Algañaraz Soria 2014). We also analyzed the proportion or frequency of citations of the use of honey, wealth of medicinal uses, mode of medicinal use and perception of the change in nests density over time. Finally, to compare the medicinal uses registered among the inhabitants of the three environments, we used the Sorensen Similarity Index (1948) as follows: $C N=2$ $(\mathrm{jN}) / \mathrm{aN}+\mathrm{bN}$. Where $\mathrm{aN}=$ the number of modes of medicinal use mentioned by group $\mathrm{A}, \mathrm{bN}=$ the number of modes of medicinal use mentioned by group $B, j N=$ number of modes of use cited in both groups.

\section{RESULTS}

\section{Native melliferous insects recognized in the region}

The villagers recognized 4 types of wild honeys produced by native Hymenoptera insects (Table 1), being that of Plebeia molesta the most cited and valued; they known it locally as "pink honey", "stick honey" or "little bee honey". Except on two occasions, this is the only wild honey to which medicinal properties are attributed and, at the same time, it is preferred as food due to its flavor. It was often described as "the best" or "the richest of all." In some cases its medicinal qualities were compared to those of the honey of Apis mellifera and highlighted that the honey of "quella" is better. In some houses, we observed bottles of pink honey harvested 5 years before. In all cases its storage was explained as good to have it at hand to use it on unexpected occasions. In $15 \%$ of the interviews, two morphs of "quella" were mentioned, taking into account differences in the size of the individuals. Only in 2 interviews do the interlocutors considered that they could correspond to two different species given that they are not observed sharing spaces but that each one is found in different localities.

Table 1. Native insects recognized as honey producers.

\begin{tabular}{c|c|l|c}
\hline Specie & Family & \multicolumn{1}{|c}{ Vulgar name } & Assigned uses \\
\hline Plebeia molesta Puls & Apidae & $\begin{array}{l}\text { Quella, queya, abeja Chiquita } \\
\text { (small bee), negrita (bold), abeja } \\
\text { de la miel rosada (pink honey } \\
\text { bee), abejita de los palos (sticks } \\
\text { bee), molesta (annoying), abeja } \\
\text { de la colmena (hive bee), vira- } \\
\text { vira, abeja de la colmena del } \\
\text { árbol (tree hive bee). }\end{array}$ & $\begin{array}{c}\text { medicinal and } \\
\text { nutritional }\end{array}$ \\
\hline $\begin{array}{c}\text { Bombus spp. } \\
\text { Brachygastra lecheguana } \\
\text { Latreille }\end{array}$ & Apidae & $\begin{array}{l}\text { Guanquero, bumbulo, } \\
\text { guanqueyra, abejorro } \\
\text { (bumblebee). }\end{array}$ & $\begin{array}{c}\text { Without } \\
\text { registered uses }\end{array}$ \\
\hline Polybia occidentalis Olivier & Vespidae & Lechiguana. & Food \\
\hline
\end{tabular}




\section{Local uses of Plebeia molesta honey}

According to the frequency of citations obtained in the interviews conducted in the three environments as a whole, the use of quella honey is destined exclusively to medicinal purposes by $31 \% ; 45 \%$ of the domestic units visited mention its use for medicinal and nutritional purposes; $21 \%$ only use it for food and 3\% keep hives in rustic boxes or guard wild colonies with a symbolic value (following a legacy of their parents, because its presence in the domestic environment promotes good fortune and / or the proliferation of domestic animals).

Regarding the uses of honey for medicinal purposes, it was recorded that $45 \%$ of the inhabitants use honey in a pure form without combinations or prior preparations. In a smaller proportion, they use honey with salt, lemon, in an infusion of "atamisqui" (Atamisquea emarginata Miers ex Hook. \& Arn, Capparaceae) -which is also valued as a medicinal plant used for respiratory diseases-, with oil, sugar or donkey milk (Figure 2).

The modes of medicinal use and combinations with different elements change

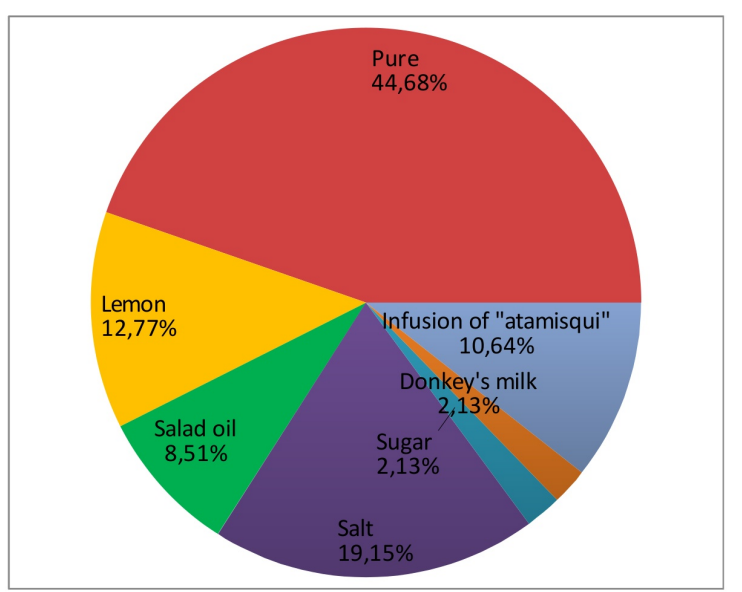

Figure 2. Modes of application for medicinal purposes. according to the environment (Figure 3). According to the Sorensen Similarity Index (Figure 4) a greater similarity is observed between the domestic units located in the Plain Forest and the Salinas Coast (90\%). Among the inhabitants of the Serrano Forest, we found 3 of the 7 different ways of registered medicinal uses, with a predominant use of pure form without combinations or previous preparations, with salt in second place and with donkey milk registered in a single appointment.

The most valuable uses of pink honey in the Northwest of Córdoba is mainly related to respiratory ailments (88.53\%: 54 citations), followed by eye, digestive and immunological disorders; it is also assigned nutraceutical properties (consume for prevention of diseases and as an energizing functional food) (Table 2).

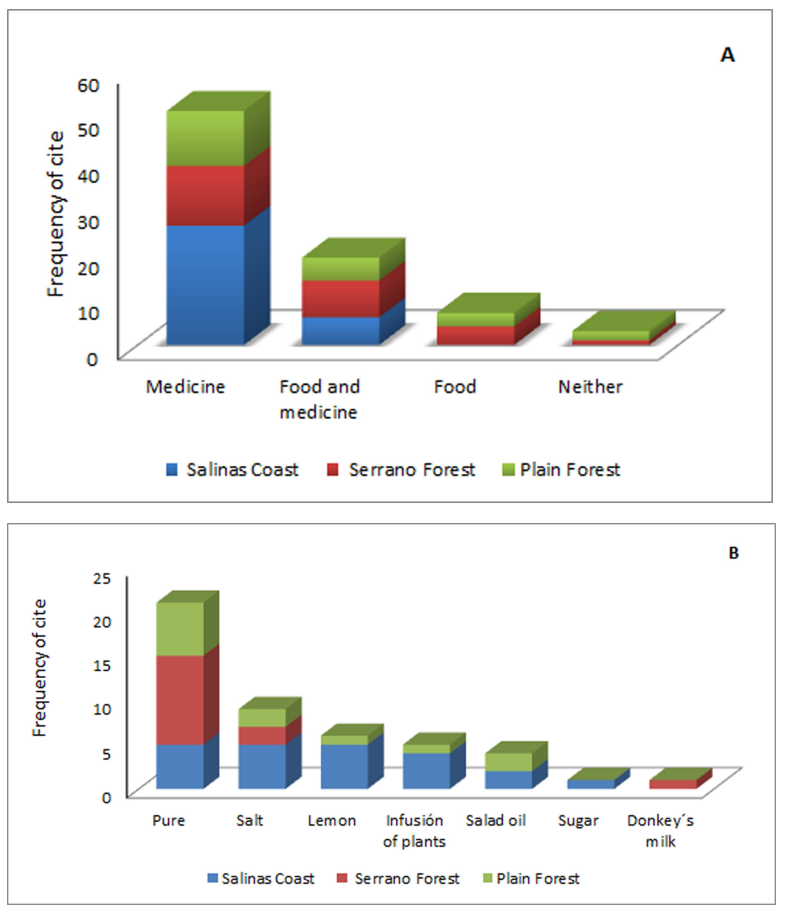

Figure 3. Modes of use of the "quella honey" (A) and methods of application for medicinal purposes (B) according to the environment. 


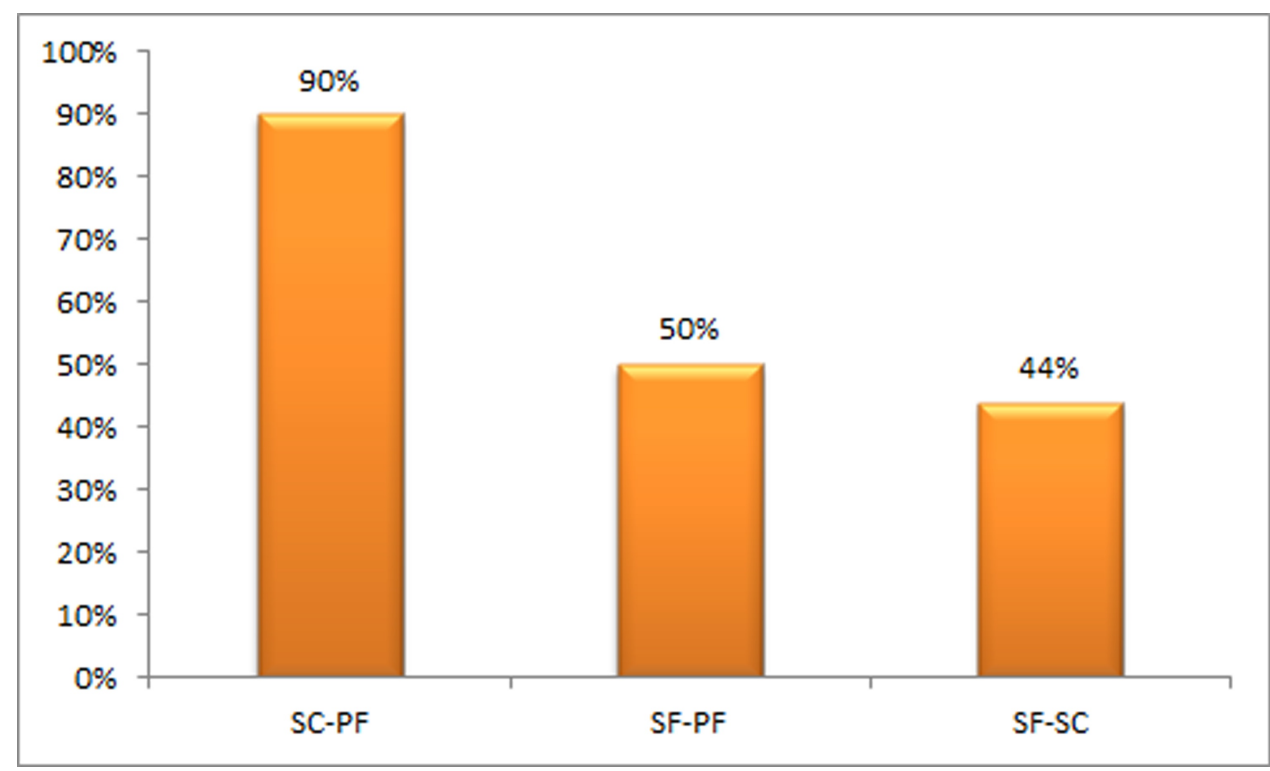

Figure 4. Similarity between environments, in the mode of application of honey for medicinal purposes according to the Sorensen Index. SC: Salinas Coast, PF: Plain Forest, SF: Serrano Forest.

Table 2. Medical use of native stingless bee honey in the Northwest of Córdoba.

\begin{tabular}{|c|c|c|}
\hline \multicolumn{3}{|c|}{ Riches of medicinal uses of pink honey } \\
\hline Body system & $\begin{array}{c}\text { Treatment in Disease / Disease } \\
\text { Prevention }\end{array}$ & $\begin{array}{l}\text { Number of } \\
\text { registered cites }\end{array}$ \\
\hline \multirow{11}{*}{$\begin{array}{l}\text { Respiratory } \\
\text { system }\end{array}$} & Sore throat & 17 \\
\hline & Cough & 9 \\
\hline & Chest pain, closed chest & 9 \\
\hline & To expel phlegm & 5 \\
\hline & Bronchitis & 4 \\
\hline & Cold / Flu & 3 \\
\hline & Convulsive cough & 2 \\
\hline & Asthma & 2 \\
\hline & Pneumonia & 1 \\
\hline & $\begin{array}{l}\text { For the expulsion of phlegm in } \\
\text { newborns }\end{array}$ & 1 \\
\hline & $\begin{array}{l}\text { False croup (laryngitis, laryngo trachea } \\
\text { bronchitis) }\end{array}$ & 1 \\
\hline \multicolumn{2}{|r|}{$\begin{array}{ll} & \text { TOTAL } \\
\end{array}$} & 54 \\
\hline Digestive system & Stomach pain in babies & 1 \\
\hline \multicolumn{2}{|r|}{$\begin{array}{ll}\text { TOTAL } \\
\end{array}$} & 1 \\
\hline Sensory System & $\begin{array}{l}\text { Improve vision in the face of general } \\
\text { diseases }\end{array}$ & 1 \\
\hline \multirow{2}{*}{\multicolumn{2}{|c|}{$\begin{array}{r}\text { TOTAL } \\
\end{array}$}} & 1 \\
\hline & & 2 \\
\hline Immune system & $\begin{array}{l}\text { Increase defenses in the first months } \\
\text { of life }\end{array}$ & 1 \\
\hline \multirow{2}{*}{\multicolumn{2}{|c|}{$\begin{array}{ll}\text { TOTAL } \\
\end{array}$}} & 3 \\
\hline & & 1 \\
\hline Integral system & General well-being & 1 \\
\hline \multicolumn{2}{|r|}{ TOTAL } & 2 \\
\hline & OVERALL TOTAL & 61 cites \\
\hline
\end{tabular}


In relation to the sensorial evaluation of honey, in general the peasants consider that it could change its characteristics according to the flowers the bee visits to produce it. However, they claim that it usually has the same reddish color - hence its vulgar name of pink honey. Only some peasants mention that the taste of honey can differ according to the species of plant (tree or cactus) in which the nest is lodged or the area of the forest in which the nest is located. They describe its taste and consistency as very sweet and smooth with fluid texture. Some expressions about its taste were: "honey is delicious", "I would give anything to eat that honey again", "it is the richest of all honeys".

Regarding the influence of cultural variables evaluated in the knowledge and medicinal uses of "quella" honey in the MCA analysis, a high variability of the information is observed. Occupation, distance to the nearest urban center and type of environment are the factors that contribute the most to explain the variability of the data, within a $21.55 \%$ of the total inertia, reached by dimension 1 and 2 . If we considered up to dimension 5, occupation would be the variable that best explains the differences within $42.62 \%$ respectively.

Perception of changes in the abundance of wild nests of Plebeia molesta

About the perception of the density of wild colonies in the territory, $75 \%$ of the interviewees considered that the frequency of encounter of nests in the forest decreased considerably in the last three decades, attributing as the main cause, clearance and change of land use. Linked to this, they identified the Protected Natural Areas and a property close to the Salinas that is characterized by having mature forest in a good state of conservation, such as places where strong nests can be found and where they can spread. $10 \%$ of the interviewees are mentions of the occurrence of changes and $15 \%$ enunciate that there was no decrease or increase in the density of nests located in mature forests in the last 30 or 40 years (Figure 5).

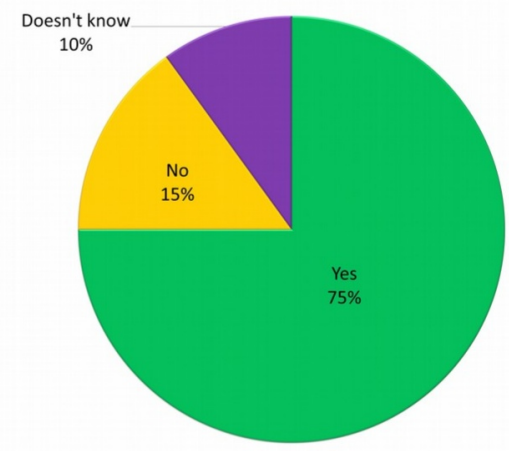

Figure 5. Decrease in the density of nests of Plebeia molesta over time, according the villagers.

Some interlocutors mentioned the high abundance of meliponas while doing their work in the forest in the past (extraction of trees for use of firewood and charcoal) and the inconvenience they caused as they are attracted to human sweat: "In time of the obraje there were so many (the bees that approached) that at the time of eating (when they made a break for lunch), we put a sheet over our face and body so they did not bother us. At night we went out to burn some nests -which we had marked during the dayto work more comfortably the following day. In this field there were many nests, because there was a lot of mature forest and lots of tentitaco (Prosopis torquata (Lag.) DC.)" (AC, Cachiyuyo, 41 years old, 09/28/2017).

Finally, it was identified that $29 \%$ of the interviewees have, or had at some time, hives in rustic boxes, in turn $71 \%$ want to learn how to handle and divide hives of 
native stingless bees, in order to obtain honey and other products mainly for family consumption. This interest in domestic breeding is generally explained as a way to stock up on pink honey without having to cut or damage forest trees or bee colonies. In the interviews done, the villagers do not show any negative opinion about learning how to manage Plebeia molesta.

Contrasted appreciations over time reflect the valuation peasants currently make of this resource. Decades ago, the "quella" was considered such an annoying insect during work in the bush, that nests were removed only with the purpose of diminishing its abundance in the workplace. Currently, this perception has changed towards a high interest in having hives at home, learn about the management of the colonies and be able to harvest honey without damaging the nest; going to the extent of recognizing nearby sites with mature forest that can "provide mother nests", among which the Protected Natural Areas are identified.

\section{DISCUSSION}

In the present work the presence of Plebeia molesta in the northwest of the Province of Córdoba is confirmed, consistent with the unique ethnospecies of native stingless bee rural inhabitants identified. Regarding the two morphotypes recognized by some farmers, it is not ruled out that they could correspond to two different species of Plebeia, since $P$. molesta and $P$. catamarcensis are cited for Córdoba; even more, if it is considered that this genus has hardly been studied in detail, as evidenced by the recent discovery of the Plebeia guazurary species in the Argentine Northeast (Álvarez et al. 2016).

The findings of this work show that the socio-cultural and occupational characteristics of rural people intervene in very different ways in the relationship of people with the uses assigned to "quella" honey. The factors that could model this process are varied and intermingled without responding to the particular qualities of the users. Therefore, future in depth studies should elucidate if any of these factors fulfill a preponderant modeling role.

In future work, it is interesting to deepen the analysis of the possible factors that influence the high variability of the results obtained, poor consensus of the population about the cultural knowledge of stingless bees honey and the low proportion of respondents under 35 years of age (14\%) referenced as key interlocutors.

In relation to the importance of these insects, there are indications that in prehispanic times many indigenous cultures of South and Central America used stingless bees honey, wax and pollen (Baquero and Stamatti 2007). The honey of "quella" does not have any economic importance as that of other genera in the north of the country (Tetragonisca, Trigona and Melipona). However, it is attributed the highest symbolic, culinary and medicinal values in the culture of Córdoba compared to other honeys produced by native hymenoptera recognized in the region. A similar assessment was made for other Plebeia species in the Yungas of northern Salta, where the diversity of melliferous insects is represented by 15 ethnospecies (Flores et al. 2018), much more numerous than that recorded in this study.

Multiple names are given tor Plebeia molesta and some could be related to linguistic systems typical of native peoples of the region. In different dialects of Quechua, "qhilla, qilla, qella, q'ella, qhella" refer to adjectives as lazy and idle (Katari.org 2017; Runasimi.org 2017; Tierra-Inca.com 2017). 
These words related to the nickname "quella" that the criollos currently use are linked to the descriptions of this bee behavior: "they leave later than the Apis", "if it's cold they do not come out", "they make little honey".

The relationship of a society with wildlife exposes different dimensions, some subtle and others more obvious (Camino et al. 2018). The relationship of the peasant culture of the Dry Chaco of Córdoba with the honey of "quella" shows both; on the one hand, it is a tangible, concrete link - the use of the resource as a source of medicine and food - and at the same time it is symbolic, and more difficult to detect, such as breeding or preserving the insects in specific places (Eg: yard posts) or boxes that belonged to a close relative. This within the paradigm "Contributions of nature to people (NPC)" would represent two of the three recognized dimensions (Díaz et al., 2018): one related to material contributions and another related to non-material contributions. According to the authors, we hope that the deepening of the studies from the NPC approach could increase the environmental governance and the associated policies that will be applied in the territory.

Regarding the use of "quella" honey, some of the forms of consumption and treatment of illnesses cited in this study coincide with those registered in northern Argentina for honeys from different ANSA species (Flores et al. 2018; Zamudio 2011). Specifically, the preponderant use of this honey as a medicine has been recorded similarly for other honeys of melipónides in the Brazilian Amazon, where some indigenous groups use it only as a remedy, without consuming it daily as a food supplement as indicated in other cases (Ferrufino Arnéz and Aguilera Peralta 2004). In the north of Córdoba, there are testimonies of the use of this honey as a home remedy: "The honey of the "panelists" bees, which are the "little bees", is good for convulsive cough and for asthmatics" related a resident of Villa Quilino (CEF, 41 years old, 04/10/2010) according to the Colectivo Relatos del Viento (2010). "People used the arrope (of honey) of the "little bee as remedy", for children, for sore throat (...)" (MG, Tuclame, 94 years old, 07/26/2012) expressed in Rionda Cortina and Rosalía (2015). These narrations expose the medicinal value attributed to the honey of "quella" in Córdoba, its application in pure state without mixtures and above the food use, of which no outstanding findings were found.

The predominant form of medicinal application is the consumption of pure honey; probably because the villagers attribute this form a heightening effect to this way of administration, so it would not be necessary to mix it with other components to achieve better results. This use is distinctive to the predominant use in combinations with medicinal herbs registered in Misiones with the honey of Tetragonisca fiebrigii (Zamudio and Hilgert 2011), and in Salta with honey of Plebeia nov. sp. (Flores et al. 2018). In general, the uses, knowledge and obtention of "quella" honey are related to the occupation of the inhabitants, the place where they live (environment) and the distance to urban centers where all basic services are offered (including basic health services), as evidenced by the MCA analysis. However, the variability of the results was high, and it promotes paying attention in future works to other factors that may be intervening in the transmission and maintenance of cultural knowledge about native bees and their honey. For example, this honey is not the only resource of the native forest used by the farmers of the 
region for medicinal purposes (Arias Toledo 2009; Arias Toledo et al. 2010; Furlan et al. 2011; Trillo et al. 2014; Trillo and Audisio 2018; Martínez and Luján 2011) which may influence the lack of consensus and the high variability observed.

Finally, $75 \%$ of the people interviewed perceive that the density of meliponas nests has decreased considerably from 30 to 40 years ago and relate this phenomenon to the destruction of native forests and the expansion of agriculture and livestock breeding. This coincides with that stated by Baquero and Stamatti (2007) and the high rates of deforestation of the departments of the northwest arch of Córdoba, which in turn present the greatest losses of native forests compared to the other provincial departments (Agost 2017).

In addition to clearance and other changes in land use, the way of extracting nests that they have practiced since ancient times is also recognized as an unsustainable practice since hives die in most cases because the colony cannot rebuild the open nest. In this way, overexploitation combined with the high rate of deforestation of the Dry Chaco of Córdoba, has implied an acceleration in the reduction of wildlife species and threatened the cultures that depend on them, as recorded in other areas of the dry Argentine Chaco (Camino et al. 2018). The use of nest traps (Gennari 2019) to obtain a swarming wild colony and the division of hives in technified boxes (Baquero and Stamatti 2007) are practices that are being developed in Argentina and Latin America, since they allow to increase and / or maintain a meliponary for harvesting honey and other products from native bees without pressing on the hives that inhabit the native forest, or damaging the host plants.

From the information obtained in this work, it is interpreted that the conservation of honey in the inhabitants' houses, their access to the resource and their interest in keeping it available is related to the possibility of achieving better health conditions, therefore, better living conditions, coinciding with the fact that the domestic units visited are located in places where health care centers are absent and / or visits by health professionals are very sporadic. This is consistent with the idea of Tapella (2012) that explains the preservation of Ecosystem Services as an unavoidable condition for social survival of small producers. Implementing strategies of management and conservation of this ANSA, with the purpose of guaranteeing this common good for the members of their close social circle, could be widely accepted by local peasants.

\section{CONCLUSIONS}

The management of beehives of "quella" and the quality of their honey are research axes that should be deepened in order to provide tools that can contribute to local work on the use and conservation of native stingless bees and the autochthonous forests of the northwest of Córdoba. Complementary research and interdisciplinary work are required to define conservation strategies taking into account the perceptions and the traditional ecological knowledge (TEK) of the populations living inside Protected Natural Areas or their zone of influence. This knowledge should be considered so that measures result efficient when implemented in the territory. At the same time it should allow to reforcing the capacity of societies to manage natural resources, especially in changing conditions or uncertain contexts (Camino et al. 2018; Manfredo and Dayer 2004; Reyes-García 2009; St John et al. 2011). 
For the peasants, it is clear that the possibility of finding a nest in the forest decreased considerably in recent decades, that the honey of "quella" is a valuable resource for the health of the domestic unit and a favorite food with respect to other honeys. They also agree that the most sustainable way of obtaining this resource is to handle Plebeia molesta in adapted boxes. These concepts are fundamental axes that will benefit the actions of preservation, protection and conservation of the ANSA in Córdoba.

Future work related to quella honey, stingless bees and the native forests of Córdoba should contribute to the appreciation and continuity of local cultures, and the development of diversified and sustainable production systems suited to the Dry Chaco in the province.

\section{ACKNOWLEDGMENT}

The authors thank the Universidad Nacional de Córdoba, the Consejo Nacional de Investigaciones Científicas y Técnicas (CONICET) and the Universidad Nacional de Misiones for the support to the $\mathrm{PhD}$ in Biological Sciences of the first author. They also thank the Secretaría de Políticas Universitarias del Ministerio de Educación de la Nación for the financing granted to the Project PCESU9-UNCOR1110

Meliponiculture in Córdoba. We thank the Dirección de Áreas Naturales Protegidas de la Secretaría de Ambiente y Cambio Climático de la Provincia de Córdoba for authorizing field work in protected natural areas and surroundings, to the Gdpque. Nicolás Maldonado and especially the Gdpque. Eduardo Martínez for his technical assistance in the field works and the permanent collaboration in this study. We are grateful to Dr. Lisandro Agost and Dr. Federico Sasatornil for their collaboration so that this article can be concretized and to the rural inhabitants of the Cordovan northwest by sharing their knowledge.

\section{REFERENCES}

Agost L (2017) Avances de las Fronteras Agropecuarias.

[http://montesdecordoba.org/factores/avance-delas-fronteras-agropecuarias] Accessed 14 August 2018.

Algañaraz Soria VH (2014) El "Análisis de Correspondencias Múltiples", una herramienta metodológica de síntesis teórica y empírica. Memoria Académica. Facultad de Humanidades y Ciencias de la Educación. Universidad Nacional de La Plata. Argentina.

Álvarez LJ, Rasmussen C, Abrahamovich $\mathrm{AH}$ (2016) Nueva especie de Plebeia Schwarz, clave para las especies argentinas de Plebeia y comentarios sobre Plectoplebeia en la Argentina (Hymenoptera: Meliponini). Rev. Mus. Argentino Cienc. Nat. 18(1): 65-74

Arenas P (2003) Etnografía y alimentación entre los Toba-Ñachilamoleek y WichíLhuku'tas del Chaco Central: Argentina. 1ed. Pastor Arenas, Buenos Aires, Argentina.

Argueta Villamar A, Sanabria Diago OL, Cano Contreras EJ, Medinaceli A (2018) Código de ética para la investigación etnobiológica en América Latina. Ethnoscientia. 3 (2).

Arias Toledo B (2009) Diversidad de usos, prácticas de recolección y diferencias según género y edad en el uso de plantas medicinales en Córdoba, Argentina. Boletín Latinoamericano y del Caribe de Plantas Medicinales y Aromáticas. 8 (5): 389 - 401.

Arias Toledo B, Trillo C, Grilli M (2010) Uso de plantas medicinales en relación al estado de conservación del bosque en Córdoba, Argentina. Ecología Austral 20:235-246.

Avendaño O (2010) El buen vivir. Una vía para el desarrollo. Alberto Acosta y Esperanza Martínez (comp.) Polis, Revista de la Universidad Bolivariana. 9 (25): 557-561.

Baquero L, Stamatti G (2007) Cría y Manejo de Abejas sin aguijón. Ediciones del Subtrópico, Tucumán, Argentina. 
Barchuk AH, Britos AH, De la Mata E (2009) Diagnóstico de la cobertura de bosques nativos de la provincia de Córdoba en Sistema de Información Geográfico. Inédito. Grupo de Investigación de Ordenamiento Territorial Participativo, Universidad Nacional de Córdoba, Córdoba, Argentina.

Berlin B (1992) Ethnobiological classification: principles of categorization of plants and animals in traditional societies. Princeton University Press, Princeton, New Jersey.

Bernard HR (2000) Social Research Methods. Qualitative and Quantitative Approaches. Sage Publications, Thousand Oaks, Londres, Nueva Delhi.

Bertonatti C (2017) Los dioses viven y mueren con la naturaleza. Informe ambiental anual 2017 FARN ed., Buenos Aires, Argentina.

Camino M, Cortez S, Altrichter M, Matteucci SD (2018) Relations with wildlife of Wichi and Criollo people of the Dry Chaco, a conservation perspective. Ethnobiology and Conservation 7:11.

Cano Contreras EJ, Medinaceli A, Sanabria Diago OL, Argueta Villamar A (2015) Código de Ética para la investigación, la investigaciónacción y la colaboración etnocientífica en América Latina. Versión uno. Etnobiología 12(4): 5-6

Colectivo Relatos del Viento (2010) Relatos del Viento. Revalorización de la Tradición Oral del Norte Cordobés. Ed. Copiar. Córdoba, Argentina.

Cosa MT, Dottori N (2010) Adaptaciones Morfológicas de las plantas vasculares. Guía de Trabajos Prácticos. Cátedra de Morfología Vegetal de la FCEF y $\mathbf{N}$ de la Universidad Nacional de Córdoba. Cosa MT, Dottori N (eds.) Córdoba, Argentina.

Cotton CM (1996) Understanding traditional plant use and management: indigenous perceptions of the natural world. Chapter 9. In: John Wiley \& Sons Ltd. (eds.) Ethnobotany: principles and applications. Chichester, Inglaterra.

De Albuquerque UP (1999) La importancia de los estudios etnobiológicos para el establecimiento de estrategias de manejo y conservación de las florestas tropicales. Biotemas 12(1): 31-47.
Díaz S, Pascual U, Stenseke M, Martín-López B, Watson RT, Molnár Z, Hill R, Chan KMA, Baste IA, Brauman KA, Polasky S, Church A, Lonsdale $M$, Larigauderie $A$, Leadley $P W$, van Oudenhoven APE, van der Plaat F, Schröter M, Lavorel S, Aumeeruddy-Thomas Y, Bukvareva E, DaviesK, Demissew S, Erpul G, Failler P, Guerra CA, Hewitt CL, Keune H, Lindley S, Shirayama $Y$ (2018) Assessing nature's contributions to people. Recognizing culture, and diverse sources of knowledge, can improve assessments. Science 359 (6373): 270-272.

$\begin{array}{lll}\text { EcoRegistros.org (2018) Registros Ecológicos } \\ \text { de } & \text { la } & \text { Comunidad. }\end{array}$ [http://www.ecoregistros.org/site/pais.php?id=2\&i dgrupoclase=2] Accessed 30 November 2018.

EFE (2016) La ONU certifica la desaparición de polinizadores y pide medidas urgentes. [https://www.efe.com/efe/america/sociedad/laonu-certifica-desaparicion-de-polinizadores-ypide-medidas-urgentes/20000013-2851605\#] Accessed 21 December 2018.

Ferrufino Arnéz U, Aguilera Peralta FJ (2004) Producción Rural sostenible con abejas melíferas sin aguijón. Ed. El País. Santa Cruz de la Sierra, Bolivia.

FAO - Food and Agriculture Organization of the United Nations (2018) Polinizadores. Biodiversidad para un mundo sin hambre. [http://www.fao.org/biodiversity/componentes/poli nizadores/es/] Accessed 06 October 2018.

Flores FF, Hilgert NI, Lupo C (2018) Melliferous insects and the uses assigned to their products in the northern Yungas of Salta, Argentina. Journal of Ethnobiology and Ethnomedicine 14: 27

Furlan V, Torres C, Galetto L (2011) Conocimiento y utilización de plantas medicinales por pobladores rurales del Bosque Chaqueño Serrano de Córdoba (Argentina). Bonplandia 20(2):285-307

Gennari GP (2019). Manejo racional de las abejas nativas sin aguijón - ANSA. Ediciones INTA. Famaillá, Tucumán, Argentina.

Grimaldi P, Trillo C (2018) Prácticas y usos tradicionales de "cerco" y "monte" por los criollos de san marcos sierras (Córdoba, Argentina). Bonplandia 27(1): 81-97

Gudynas E (2011) Buen vivir: Germinando alternativas al desarrollo. América Latina en Movimiento. ALAI.N462: 1-20 
Harris O (1986) La unidad doméstica como una unidad natural. Nueva Antropología 8(30):199-222

Hilgert NI (2007) Etnobotánica como herramienta para el estudio de los sistemas de clasificación tradicionales. In: ContrerasRamos A, Cuevas-Cardona C, Goyenechea I, Iturbe $U$ (eds.) La Sistemática, base para el conocimiento de la biodiversidad. Universidad Autónoma del Estado de Hidalgo, Pachuca, México. pp.103-111.

Hilgert NI, Gill G (2006) Medicinal plants of the Argentine Yungas plants of the Las Yungas biosphere reserve, Northwest of Argentina, used in health care. Biodiversity and Conservation 15:2565-2594

ICl Forestal (2018) Las Abejas han sido declaradas la Especie más Importante del Mundo. (In: Instituto de Ciencia e Investigación. Servicio de Prensa Forestal. Uruguay) [http://www.iciforestal.com.uy/elmundo/10749-las-abejas-han-sido-declaradas-laespecie-mas-importante-del-mundo]

http://www.iciforestal.com.uy/el-mundo/10749las-abejas-han-sido-declaradas-la-especie-masimportante-del-mundoAccessed15 October 2018.

INTA (2014) Abejas sin aguijón, aliadas de la medicina.

[http://intainforma.inta.gov.ar/?p=22312]

Accessed 20 June 2015

Instituto de Botánica Darwinion (2018). Flora del Conosur.

[http://www2.darwin.edu.ar/Proyectos/FloraArgen tina/fa.htm] Accessed 15 November 2018.

IPBES (2016). Resumen para los responsables de la formulación de políticas del informe de evaluación de la Plataforma Intergubernamental Científico-normativa sobre Diversidad Biológica y Servicios de los Ecosistemas sobre polinizadores, polinización y producción de alimentos. [https://reliefweb.int/sites/reliefweb.int/files/resour ces/SPM_Pollination_ES.pdf] Accessed 21 December 2018

ISE (2006) Código de ética. International Society of Ethnobiology.

Kamienkowski NM, Arenas P (2012) Explotación de himenópteros melíferos entre etnias del Gran Chaco: Una mirada etnobiológica. Memorias XCIMFAUNA. Comunidad de Manejo de Fauna Silvestre (COMFAUNA) Ed. $\begin{array}{llr}\text { Katari.org (2017) Diccionario Quechua - } \\ \text { Aymara } & \text { al } & \text { español. }\end{array}$ [http://www.katari.org/diccionario/diccionario.php ?listletter=aymara\&display=8] Accessed 20 May 2018.

Kujawska M, Zamudio F, Hilgert NI (2012) Honey-Based Mixtures Used in Home Medicine by Nonindigenous Population of Misiones, Argentina. Evidence-Based Complementary and Alternative Medicine. 2012:1-15

Lázaro A, Tur C (2018). Los cambios de uso del suelo como responsables del declive de polinizadores. Ecosistemas 27(2): 23-33.

Loiácono MS, Margaría C, Giovannetti MA, Silva $S$ (2016) Antropo-entomofagia en grupos lingüísticos Guaycurú de Argentina: pasado y presente. Journal of Insects as Food and Feed 2(1): 15-26

Manfredo J, Dayer AA (2004) Concepts for exploring the social aspects of human-wildlife conflict in a global context. Human Dimensions of Wildlife 9: 317-328

Martínez GJ (2010) Los remedios naturales en la prevención y cuidado de la salud oral de los tobas del Chaco Central (Argentina). Boletín Latinoamericano y del Caribe de Plantas Medicinales y Aromáticas 9(2):109-122

Martínez GJ, Luján MC (2011) Medicinal plants used for traditional veterinary in the Sierras de Córdoba (Argentina): an ethnobotanical comparison with human medicinal uses. Journal of Etnhnobiology and Ethnomedicine. 7 (1): 23

Medrano MC, Rosso CN (2010) Otra civilización de la miel: utilización de miel en grupos indígenas Gaycurúes a partir de la evidencia de fuentes Jesuitas (Siglo XVIII). Espaso Ameríndio. 4(2): 147-171

Michener CD (2007) The bees of the world. 2nd ed. The John Hopkins University Press, Baltimore, Maryland, EEUU.

Morello J, Rodriguez AF, Silva M (2012) Ecorregión del Chaco Seco. Capítulo 4. In: Orientación Gráfica (ed.) Ecorregiones y Complejos ecosistémicos argentinos, Buenos Aires, Argentina, pp.159-204.

Moure's Bee Catalogue (2018)

[http://moure.cria.org.br/catalogue] Accessed 08 November 2018. 
Movimiento Nacional Campesino Indígena (2010) Movimiento Campesino de Córdoba. [http://movimientoscampesinosargentinos.blogsp ot.com/2010/07/el-movimiento-campesino-decordoba-nace_894.htm] Accessed 01 September 2018.

Nieves-Aldrey JL, Fontal-Cazalla FM, Fernández F (2006). Filogenia y evolución de Hymenoptera. Capítulo 3. In: Fernández F, Sharkey MJ (eds). Introducción a los Hymenoptera de la Región Neotropical. Universidad Nacional de Colombia, Sociedad Colombiana de Entomología SOCOLEN. Bogotá, Colombia, pp. 37-56.

Posey DA (1987a). Etnobiología: Teoria e práctica. In: Ribeiro B (ed.) Suma etnológica brasileira - 1. Etnobiologia. Vozes/Finep, Petrópolis, pp. 15-251.

Posey DA (1987b) Etnobiologia y ciencia "folk": su importancia para la Amazonia. Hombre y Ambiente. 1: 7-26

Puigrós A (2006) Que pasó en la educación argentina: Breve historia desde la conquista hasta el presente. 1ra. Ed. 2da reimpr. Galerna SRL. Buenos Aires, Argentina.

Reyes-García V (2009) Conocimiento ecológico tradicional para la conservación: dinámicas y conflictos. Rev. Papeles 107:3955

Rionda Cortina P, Rosalía PF (2015) Relatos del viento. Volumen II. Recopilación de Tradiciones Orales del Norte, Noreste y Noroeste de la Provincia de Córdoba, Argentina. 2da. Ed. Copiar. Córdoba, Argentina.

Roig Alsina A, Vossler FG, Gennari GP (2013) Stingless bees in Argentina. In: Vit $P$, Pedro SRM, Roubik DW (eds.) Pot-Honey: A Legacy of Stingless Bees. Springer, pp.125-134.

Runasimi.org (2017) Diccionario Quechua. [http://www.runasimi.org/cgi-bin/dict.cgi]

Accessed 22 May2018.

Sánchez C (2013) Caracterización del territorio Noroeste de Córdoba. $1^{\circ} \mathrm{Ed}$. Ediciones INTA. Estación Experimental Agropecuaria Manfredi. Manfredi, Córdoba, Argentina.

Serrano A (1945) Los Comechingones. Imprenta de la Universidad de Córdoba, Córdoba, Argentina.
Silvetti F (2010) Estrategias campesinas, cambios en el uso de la tierra y representaciones sociales sobre los servicios ecosistémicos en el Chaco Árido. Un análisis sociohistórico en el departamento Pocho (Córdoba, Argentina). DThesis, Universidad Nacional de Córdoba, Córdoba, Argentina.

Soldati GT (2015) Knowledge Transmission: The Social Origin of Information and Cultural Evolution. Chapter 7. In: Albuquerque UP, Muniz De Medeiros P, Casa A (eds.) Evolutionary Ethnobiology. Springe, Cham, pp.89-104

Sorensen T (1948) A Method of Establishing Groups of Equal Amplitude in Plant Sociology Based on Similarity of Species, and its Application to Analyses of the Vegetation on Danish Commons. K. DaniskeVidensk. Selsk. Biol. Skr. 5 (4):1-34.

St John FA, Edwards-Jones G, Jones JP (2011) Conservation and human behaviour: lessons from social psychology. Wildlife Research 37(8): 658-667.

Stagnaro M (2016) Pueblos indígenas en Santiago del Estero y Córdoba. Tejiendo memorias con relatos actuales. 1ra. Ed. Ministerio de Educación y Deportes de La Nación. Ciudad Autónoma de Buenos Aires, Argentina.

Suriano J, Lobato MZ (2013) Atlas histórico: Nueva Historia Argentina. Sudamericana. Buenos Aires, Argentina.

Tálamo A (2006) Biodiversidad de plantas leñosas y disturbios humanos en el bosque chaqueño semiárido: Efectos del aprovechamiento forestal. DThesis, Universidad de Buenos Aires, Buenos Aires, Argentina.

Tapella E (2012) Heterogeneidad social y valoración diferencial de servicios ecosistémicos. Un abordaje multi-actoral en el oeste de córdoba (Argentina). DThesis, Universidad Nacional de Córdoba, Córdoba, Argentina.

The Nature Conservancy (TNC), Fundación Vida Silvestre Argentina(FVSA), Fundación para el Desarrollo Sustentable del Chaco (DeSdelChaco) y Wildife Conservation Society Bolivia (WCS) (2005) Evaluación Ecorregional del Gran Chaco Americano / Gran Chaco Americano Ecoregional Assessment. Fundación Vida Silvestre Argentina. Buenos Aires, Argentina. 
Tierra-Inca.com (2017) Diccionario Español Quechua.

[https://www.tierrainca.com/dico/view.php?lg=es\&lg1=es\&lg2=ke\&o $\mathrm{pt}=111110 \& \mathrm{pg}=\mathrm{p}]$ Accessed 20 May 2018.

Toledo VM, Batis Al, Becerra R, Martínez E, Ramos CH (1995) La selva útil: la etnobotánica cuantitativa de los grupos indígenas del trópico húmedo de México. Interciencia. 20: 177-187

Torres GF, Santoni ME, Madrid L, Romero LN, Barbaran FR (1998) Alimentación y nutrición de los Matacos del Pilcomayo. Un estudio Antropológico. Revista Andes 10:1-19.

Trillo C, Demaio P, Colantonio S, Galetto L (2007) Conocimiento actual de plantas tintóreas por los pobladoresdel valle de Guasapampa, provincia de Córdoba. Kurtziana. 33 (1): 65-71

Trillo C, Colantonio S, Galetto L (2014) Perceptions and Use of Native Forests in the Arid Chaco of Córdoba, Argentina. Ethnobotany Research \& Applications. 12:497510

Trillo C (2016) Prácticas tradicionales de manejo de recursos vegetales en unidades de paisajes culturales del oeste de la provincia de Córdoba, Argentina. Zonas Áridas 16(1): 86111

Trillo C, Arias Toledo B, Colantonio S (2016) Uso y percepción del bosque por pobladores de diferente tradición cultural de la Laguna de Mar Chiquita, Córdoba, Argentina. Ecologia Austral. 26 (1): 7-16

Trillo C, Audisio C (2018) Las plantas medicinales de los huertos de pobladores de diferente tradición cultural en Bosques Chaqueños de Córdoba, Argentina. Boletín Latinoamericano y del Caribe de plantas medicinales y aromáticas. 17 (2): 104-119
UICN. (2016). Informes de evaluación de biodiversidad sobre polinización en escenarios y modelos lanzados. [https://www.iucn.org/es/news/secretariat/201612 /informes-de-evaluaci\%C3\%B3n-de-

biodiversidad-sobre-polinizaci\%C3\%B3n-en-

escenarios-y-modelos-lanzados] Acceso 21 Diciembre 2018

Vitar B (2000) El impacto de la expulsión de los jesuitas en la dinámica fronteriza del Tucumán.

[https://core.ac.uk/download/pdf/71612652.pdf]

Accessed 1 June 2017

Zamudio F, Kujawska M, Hilgert NI (2010) Honey as Medicinal and Food Resource. Comparison between Polish and Multiethnic Settlements of the Atlantic Forest, Misiones, Argentina. The Open Complementary Medicine Journal 2: 58-73

Zamudio F (2011) Conocimientos locales y manejo de las abejas sin aguijón (Apidae: Meliponinae) entre los pobladores rurales del Norte de la Provincia de Misiones. DThesis, Universidad Nacional de Córdoba, Córdoba, Argentina.

Zamudio F, Hilgert NI (2011) Mieles y plantas en la medicina criolla del norte de Misiones, Argentina. Bonplandia. 20(2): 165-184

Zamudio F, Hilgert NI (2012) ¿Cómo los conocimientos locales aportan información sobre la riqueza de especies de abejas sin aguijón (Apidae: Meliponini) del Norte de Misiones, Argentina? Interciencia 37(1): 36-43

Zamudio F, Hilgert NI (2017) Cultural, Psychological and Organoleptic Factors Related to the Use of Stingless Bees by Rural Residents of Northern Misiones, Argentina. Chapter 20. In: Patricia Vit, Silvia R. M. Pedro, David Roubik (eds). Pot-Pollen in Stingless Bee Melittology. Springer, New York, pp.283-297.
Received: 26 January 2019

Accepted: 30 April 2019

Published: 30 August 2019 